\title{
The Effectiveness of Fourth U.S. Quantitative Easing Policy on China
}

\author{
Xinyue Guo ${ }^{1, \dagger, *}$, Xinyi Liu $^{2, \dagger}$, Ziqi Yang ${ }^{3, \dagger}$ \\ ${ }^{1}$ International College Beijing, China Agricultural University, Beijing, 100083, China \\ ${ }^{2}$ School of Humanities, Social Sciences \& Law, Harbin Institute of Technology, Harbin, 150000, China \\ ${ }^{3}$ School of Economics, Nankai University, Tianjin, 300071, China \\ *Corresponding author.Email: guanghua.ren@gecacdemy.cn \\ These authors contributed equally.
}

\begin{abstract}
As COVID-19 swept the world, the economies of many countries were mauled heavily. Consequently, the United States promoted the fourth Quantitative Easing policy (QE4) to stimulate economic growth, but this policy would also have some impacts on other economies. Therefore, the study chooses the U.S.QE4 as the independent variable and the Chinese economic market as the dependent variable to discuss the impact of the U.S. QE4 on the Chinese financial market. After investigating the factors of the QE4 in the United States, and analyzing the specific impact of the QE4, this article carried out a SWOT analysis, dividing the impact of QE4 in the United States on China into four aspects (strength, weakness, opportunity, and threat). As for strengthening, QE4 created opportunities for China to promote and upgrade economic transformation. However, as for weakness, QE4 affected Chinese domestic markets, including Chinese companies, consumers, prices, etc. Regarding to the opportunity, QE4 improved the internationalization of the RMB and enhanced the status of the RMB. Whereas, as for threatening, QE4 was related to the appreciation of the $\mathrm{RMB}$, leading to a deterioration of trades and risks to financial markets. In summary, QE4 hurt China as a whole. To cope with the effects, China should make steps related to GDP, commodity prices, etc. Moreover, China needs to change its strategies to develop its economy, being prepared to prevent the U.S. from withdrawing from the QE4 and implementing QE policy in the future. This paper makes an objective analysis of quantitative easing policy from different periods to help people understand the policy comprehensively and correctly, summaries positives and negatives impacts on China from the policy, and puts forward some constructive suggestions for other countries to deal with the negative effects from the policy.
\end{abstract}

Keywords: U.S. Quantitative Easing policy, COVID-19, Monetary Policy

\section{INTRODUCTION}

With COVID-19 sweeping the world, the economy of many countries has been hit significantly. During the COVID-19, many countries were suffering from large factory production stoppages, high unemployment rates, slower-growing or even lower per capital income, reduced commodity demand, lower consumption levels, and lagging economic development. According to Mou, "global GDP will fall by as much as 3\%" [1]. As the world's largest economy, the United States also has not been able to avoid the economic impact brought by COVID-19. The FOMC argues that COVID-19 must have seriously damaged the economic activities of many countries [2]. For example, in the United States, "GDP decreased $3.5 \%$ in 2020 , the lowest growth rate since
1946" and "the average annual unemployment rate in 2020 was 8 . 1\%", which is a serious situation [3]. Then many countries have taken action to cushion the economic impact brought by COVID-19, and the United States has implemented QE4, since March 2020 to resist the economic crisis brought by COVID-19. "QE is a monetary policy whereby a central bank purchases at scale government bonds or other financial assets to inject money into the economy to expand economic activity" (From "Frequently asked questions". Bank of England. ). After noticing the impact of COVID-19 on the economy, the Federal Reserve decided to implement QE4 and "slashed the target fed fund rates, the interest depository institutions charge one another overnight for reserves, to between 0.0 and 0.25 percent" [2]. 
This is not the first time that $\mathrm{QE}$ has appeared. Previously, many countries implemented QE to stimulate economic recovery in the face of an economic crisis. For example, the Bank of Japan implemented a QE policy from 2001 to March 2006, which significantly alleviated the deflationary pressure of Japan's economy in 2006. Afterward, the United States also implemented QE in 2008 to deal with the global financial crisis, and Europe also implemented QE in 2015. As an important monetary policy, there have been many pieces of research on QE before. Previous studies mainly focus on the impact of QE policies in Japan, the United States, and Europe under the background of the financial crisis, including measures like zero interest rate, expanding financing, and purchasing treasury bonds. These studies indicate that QE policy can effectively pull domestic demand and stimulate the economic growth of the implementing countries in the short term. However, they can negatively affect economies outside the implementing countries like inflation and undermining financial stability. For example, in Bernanke's opinion, the "'flexible' and 'open-ended' large-scale asset purchases" can "ease financial conditions and spur faster growth", while Guido Mantega states that developing countries can't "passively endure the spillovers of advanced countries' policies through large and volatile capital flows and currency movements, which is a selfish policy that weakens the efforts for concerted action" [4]. According to previous studies, although the low interest rate or even zero interest rate after the implementation of QE4 in the United States can stimulate the U.S. economy in the short term, the implementation of QE4 in the United States will have an impact not only on the United States' economy but also on other economies and even the global economy. Therefore, under the severe situation that the global economy is impacted seriously by COVID-19, it is very important to understand the impact of $\mathrm{QE}$ policy on economies outside the implementing countries and take corresponding countermeasures. Although many previous studies have put forward views on the economic impact of QE on developing countries, the impact of QE4 under the background of COVID-19 on other economies and how other economies should respond still need more research since it is a new situation related to the global epidemic and health economy. China is the world's second-largest economy except for the United States and has not adopted QE policy in the face of the impact of COVID19 on the economy. Therefore, the paper selects China as the independent variable. By analyzing the changes in China's interest rate, inflation rate, commodity price, exchange rate, and foreign capital inflow after the implementation of QE4 in the United States, we obtain the short-term and long-term impact of the United States' QE4 on China's economic market. Hence, the research question is what kind of short-term and longterm impact does the United States' QE4 bring to
China's economic market. This research plays a vital role in enabling China's economic market to better understand the impact of the United States' QE4 and formulate corresponding policies to deal with the impact of COVID-19 and QE4 on China's economy. Meanwhile, it can be used as a reference for other economies that do not implement QE4 to better face the current epidemic and economic situation.

This article firstly does some literature review on studies about previous QE policies and their impacts and explains some background knowledge. Then, this article uses the SWOT analysis method to illustrate what positive internal impacts, positive external impacts, negative internal impacts, and negative external impacts the United States' QE4 after COVID-19 brings to China. Finally, this paper concludes that whether QE4 has a positive or negative impact on China as a whole, and puts forward suggestions on internal and external countermeasures to China. In the meantime, this research also clarifies the limitations and future expectations .

\section{LITERATURE REVIEW}

The QE policy is an unconventional monetary method that uses low or zeroes interest rates to inject liquidity into the market through the purchase of treasury bonds to respond to the economic crisis and promote economic recovery [4]. This policy originated in Japan in 2001 and has since been used many times by various countries. Based on the theory of inflation, the QE policy exceeds the U.S. dollar and lowers interest rates, which will increase currency liquidity and flow into the world's currency markets, eventually leading to world inflation and instability of the global market economy. In 2012, Liu and Zhang pointed out that the QE policy has significantly reduced the unemployment rate for the country [6]. Besides, the financial market has recovered rapidly, but QE can only stabilize and boost the economy in the short term, which is difficult to achieve long-term economic growth [6]. According to the analysis of employment rate and output value, Richard Koo also put forward the same view in 2014 [8]. Yao Bin believes that the U.S. monetary easing policy can promote the recovery of the U.S. economy, but it will have an impact on developing countries [5]. In 2021, after Ye passed QE4, China's money supply and price level fluctuations, and other factors proved this view [7].

\section{1. Impact during $Q E 1 \& Q E 2$ in the U.S.}

In 2009, Bin Yao pointed out that to deal with the subprime crisis, the United States, Britain, Japan, and other developed countries adopted QE monetary policy by directly buying their long-term treasury bonds in 2008 to stabilize and stimulate the economy, financing 
fiscal deficits and reducing long-term interest rates [5]. They said that such extreme market rescue measures have caused great external pressure on the monetary policies of emerging market economies, including China, and have had a far-reaching impact on global politics, economy, and finance [5]. On the positive side, QE monetary policy will enhance the expectation of faster recovery of the U.S. economy, ease the credit contraction in the global financial market, alleviate the deflationary pressure, and help developing economies get benefits in the short term. Nevertheless, from a negative perspective, $\mathrm{QE}$ will breed long-term inflation expectations in the market and may lead to more serious inflation under certain conditions. Meanwhile, QE will cause commodity prices to fluctuate upward, and lead to the appreciation and depreciation of the real effective exchange rate of RMB in the short term.

In 2012, Liu and Zhang pointed out that after the outbreak of the subprime mortgage crisis, the downward trend of the U.S. economy was curbed, the stock market rose, the long-term interest rate fell, and the unemployment rate increased [6]. At the same time, the Greek sovereign debt crisis broke out suddenly in 2010 and spread to other European countries, leading the global economy to face greater uncertainty. In this case, the Federal Reserve had launched the second round of QE policy in November 2010, resulting in a sharp decline in the unemployment rate and rapid recovery in the financial market. On the whole financial market, however, is difficult for QE policy to solve the problem of insufficient total demand globally. Additionally, the current real interest rates in Europe, the United States, and Japan have reached or are closing to the zerointerest-rate level. Using QE to stimulate the economy again can only stabilize and boost the economy in the short term, and it is difficult to achieve the purpose of stimulating economic growth in the long term. Looking at the impact of QE on the Chinese financial market, from the perspective of short-term trends, QE policy is conducive to stabilizing China's import and export and alleviating the negative impact of sudden changes in foreign demand on the domestic economy. Second, it is contributing to easing the pressure of capital outflow and reducing the difficulty of monetary policy regulation. Third, it is effective to improve expectations and increase the enthusiasm of manufacturers for production and investment. Fourth, it is helpful to invigorate the domestic financial market and increase the support of direct financing to the real economy. However, in terms of the long-term trend, QE policy is: first, the QE policy injects a large amount of liquidity into European and American financial institutions. Once the transfer to the real economy is accelerated, it will quickly push up the international commodity prices, increase the raw material costs of domestic enterprises, and rise the imported inflation pressure up. Second, the RMB may appreciate again and the fluctuation range will expand. Third, the pressure on maintaining and increasing the value of foreign exchange reserves has increased.

\section{2. Impact during QE3 in the U.S.}

In 2013, regarding the implementation of QE3 in the United States, Liao and others pointed out that QE3 in the United States would increase the price of bulk commodities, the global expansion is expected to continue, and the inflow of hot money into various countries led to structural asset bubbles [9]. Zhang and others also put forward similar views. They also pointed out that the influx of hot money brought about by the QE policy into emerging markets will not only be difficult to have the expected impact on the United States, but will also lead to the bubble of the global economy, laying hidden dangers for subsequent crises [10]. A 2015 study by Ma and others believes that the loose policies of the United States have a huge negative spillover effect on the economies of China and other BRICS countries [11].

\section{3. Impact during QE4 in the U.S.}

In Mosser's opinion, QE4 plays an important role in stabilizing the market, especially the credit environment, and stimulating the real economy in the early stage of COVID-19 sweeping the global economy [12]. He believes that loose monetary policy and support for the real economy from low borrowing rates have greatly stabilized financial conditions. Massive liquidity and large-scale asset purchases by the central bank quickly stabilized the market in March and April, and credit programs for the real economy gave investors confidence to face the economic turmoil caused by the pandemic [12]. However, according to Zhang's analysis of the impact of Fed monetary policy on emerging markets especially on their external debt, QE4 makes emerging markets face higher financial risk [13]. He states that although the reduction of liquidity in emerging market countries caused by massive capital outflow in 2020 can reduce the capital outflow risk caused by The Bond purchase by the Federal Reserve to a certain extent, emerging market countries will still face large-scale foreign debt risk with the contraction of U.S. dollar liquidity and the gradual tightening of global financial conditions [13].

\section{4. Summary}

Overall, these studies outline that the QE policy has different effects on the exchange rate, commodity prices, inflation expectations, financial markets, unemployment rate, and foreign exchange reserves of the policy issuing country and other countries through interest rate changes. In general, the QE policy has a limited shortterm impact on the country that implements the policy 
in promoting economic recovery, increasing employment rates, and restoring investor confidence, but in the long run, after the policy is withdrawn, it will lead to more serious asset bubbles and economic crises. As for foreign countries, researchers generally believe that the QE policy is passing on the crisis and harms foreign countries through currency spillover effects.

However, in the context of the COVID, the QE policy has new characteristics and new effects, so more research should be done on how the QE policy influence China and other countries under such a situation.

\section{METHOD}

\section{1. Research Design}

This article adopts the SWOT analysis method to divide the impact of the QE4 policy of the United States on China into four aspects: China's internal favorable effects, China's internal adverse effects, China's external opportunities, and China's external threats. This study adopted the SWOT research method as it is logically clear and intuitive, and suitable for categorizing the factors of complex QE policies. Previously, Huang and Yi used qualitative research methods on the QE policy of the United States in 2011 and 2014 respectively, and concluded that the QE policy has exacerbated market uncertainty and adversely affected emerging markets, which is of great reference significance $[14,15]$.

\section{2. Introduction of Research events}

The research object of this article is the QE4 policy in the United States. With the spread of the COVID-19 epidemic in the United States, economic activities were forced to stop, the capital market fluctuated sharply, the stock market melted four times in a short period, the unemployment rate rose, and the U.S. economy was in trouble. economic recession. To revive the economy, the United States adopted the QE4 policy. In addition to lowering interest rates to zero twice, the United States also adopted the following measures. The U.S. Federal Open Market Committee has announced that it will purchase at least U.S. $\$ 500$ billion in Treasury bonds and at least U.S. $\$ 200$ billion in mortgage-backed securities markets [16]. In addition, the Federal Reserve has launched two large-scale corporate credit facilities with a total scale of up to U.S. $\$ 750$ billion. The mechanism of purchasing commercial paper for financing has established a financing project totaling U.S. $\$ 300$ billion to strengthen credit flows [16]. QE4 greatly restored confidence in the U.S. stock market and bond market and promoted economic recovery.

\section{3. SWOT}

\section{3. 1. Strengthen}

In terms of China's internal impact, QE policy allows China to change the strategic objective and development direction. Summing the effects of four times QE policies of the United States and combining the experiences related to the past and the present $\mathrm{QE}$ policy, it is a better chance for China to make predictions of QE policies, which will conducive for China to formulate economic development strategies, accelerating and optimizing industrial upgrading, changing the mode of economic growth and promoting industrial innovation and development. Secondly, QE policy allows China to adjust the structure of Chinese foreign exchange reserves, improve the role of the government in overseas investment, inject a large number of funds, solve the problem of social demand, reduce the proportion of U.S. dollar assets and reasonably adjust the currency proportion of foreign exchange reserves. In the meantime, the Chinese government can set plans about Chinese further expanding domestic demand and adjust the economic development pattern according to the condition of the market, . For example, in April 2020, after the United States implementing unlimited QE policy to respond to the COVID-19, to ease the impact from the U.S. , China promoted a proposal to build a new development pattern: domestic large cycle as the main body and both domestic and international double cycles promoting each other, making use of the advantages of domestic and international markets and resources, focusing on domestic cycle, and cultivating China's new advantages in participating in international cooperation and competition. It has indeed effectively promoted the development of the Chinese open economy to a higher level and added new impetus to Chinese economic development.

\section{3. 2. Weakness}

The depreciation of the U.S. dollar has caused commodity prices to rise. The global economic recovery and the depreciation of the U.S. dollar have brought about an increase in the demand for investment in commodities, while the supply of raw materials producing countries affected by the epidemic has decreased, which has led to an increase in commodity prices. The increase in shipping costs caused by the epidemic has also further pushed the prices of bulk commodities to remain high. China is an importer in the bulk commodity market, i.e. , the bargaining power of enterprises is weak. Rising commodity prices have led to increased production costs and reduced profit margins for Chinese domestic companies, which in turn threatens the survival of companies. It will also cause companies to have to raise product prices, which in turn 
will increase the cost of living of residents and affect China's economic recovery. Additionally, the increase in commodity prices means that the production cost of related products will increase, the price will increase, and the dollar will depreciate. Consequently, it leads to a rise in the relative price of China's export products and a decrease in household consumption expenditure, which is not conducive to economic recovery. The third point is that the QE4 policy affects China's laborintensive industries and increases the unemployment rate. The depreciation of the U.S. dollar has increased the relative prices of Chinese export products, weakened the competitiveness of low-priced labor-intensive products, and reduced sales, which may endanger the operation of labor-intensive enterprises and increase the unemployment rate of related industries.

\section{3. 3. Opportunity}

In terms of China's external influence, the U.S. QE policy has ensured the stability of the international financial market to a certain extent, i. e. , the Chinese market has not been strongly impacted. In other word, the reason is that the United States, as an international financial center, its currency, the U.S. dollar, is linked to currencies of various countries. Then, the Federal Reserve has stabilized the U.S. financial market by issuing a large number of currencies in the short term, which means stabilizing the global market, including China. Meanwhile, the additional issuance of a large number of U.S. dollars will greatly lose people's trust in the international currency. At this time, it creates good conditions and opportunities for China to improve the international status of RMB and promotes the internationalization of RMB, effectively improving the competitiveness of striving for international pricing power, reducing the impact of foreign QE policies, and decreasing the pressure of imported inflation.

\section{3. 4. Threaten}

After the fourth quantitative easing, the U.S. dollar depreciated, and the RMB experienced volatility from the second quarter of 2020 on the overall trend of continuous appreciation starting from the second quarter of 2020, and the price competitiveness of China's export products decreased. In the meantime, the United States improved its terms of trade by devaluing the U.S. dollar and increased its competitiveness in the world market, thereby deteriorating China's terms of trade and hindering its export trade.

\section{RESULT}

In terms of Chinese internal influence, the U.S. QE policy creates opportunities for China to improve its economic development strategy, promote economic transformation and upgrading, and gain great development in the long term. However, after the fourth quantitative easing, global commodity prices have remained high, affecting the operating profits of relevant domestic companies in China, further increasing consumer product prices, reducing residents' willingness to consume, reducing residents' income and consumer spending. Moreover, it also affects some labor-intensive industries (e.g. , construction industry) and thus increasing the unemployment rate.

In terms of China's external influence, the U.S. QE policy promotes China to improve the internationalization of RMB, help increase the international status of RMB and enhance the competitiveness of RMB in the global currencies' market. Nevertheless, the relative appreciation of the RMB, the deterioration of China's terms of trade, have hindered foreign trade. Additionally, in the QE policy, a large amount of hot money flows into China. Besides, after the QE policy is withdrawn, hot money flows out of the market quickly, leading to increased market uncertainty and exposing structural imbalances.

\section{DISCUSSION}

After the COVID-19, the fourth QE policy of the U.S. has a significant negative impact on the Chinese financial market. It indeed decreases Chinese GDP, reducing residents' income and consumption expenditure. Moreover, imported inflation increased the difficulty of macroeconomic regulation and control, improving the risk of China's capital flow, and leading to the difficulty of foreign exchange management, resulting in the pressure of RMB appreciation, which is easy to have a huge impact on China's foreign trade.

Compared with the previous article, this article focuses on the QE4 policy in 2020 in this special time. Compared with the previous three times, the economic crisis solved by the QE policy this time was not caused by internal operating problems of the economic system but was impacted by external factors. The conclusions of this article are basically in line with previous research. It's obvious that QE policies are good and bad for China, but overall the negative impacts outweigh the positive impacts. The new situation validates the previous quantitative easing research.

First of all, to cope with the impact of higher commodity prices, China must implement a more open import and export policy to make the import and export of bulk commodities more convenient, reduce shipping costs. Simultaneously, it is necessary to invest in domestic reserves. Meanwhile, China must strengthen market supervision to prevent substantial price increases in the market, and subsidize downstream companies to balance consumer market prices at the same time. Secondly, to cope with the reduction in household consumption expenditure, the first is that the Chinese 
government can issue consumer subsidies and consumer vouchers to stimulate consumption. Besides, China should increase investment in domestic emerging industries to stimulate consumption with investment. Furthermore, China can increase the confidence of residents' consumption willingness and economic expectations by increasing social security. Finally, in the case of construction and other industries being impacted, China can protect the unemployed workers affected by QE4 through unemployment assistance and provide them with re-employment training to reduce the impact of QE4 on China's unemployment rate.

On this basis, China should continue to promote the internationalization of the RMB, promote changeable financial cooperation, actively participate in the establishment of the international monetary system and the reform of the international financial system, and enhance the RMB's international voice. Second, China should conduct trade negotiations with other countries through strategies, e.g. , the "One Belt, One Road" initiative to increase trade flexibility and reduce foreign trade losses caused by the relative appreciation of the RMB. Third, to increase export trade, it is necessary to increase the technical content of export products and the added value of export trade. Promoting the transformation of China's processing trade and vigorously developing service trade can reduce the impact of U.S. monetary policy on China's import and export trade.

\section{CONCLUSION}

In summary, we investigate the impact of the fourth unlimited QE policy of the United States on China after COVID-19 and demonstrates the effects based on SWOT analysis method. According to the analysis, the United States' QE4 has a positive impact on China internally and externally, e.g. , promoting China's industrial innovation and development. However, it has a larger negative impact on China, e.g. , the depreciation of the U.S. dollar and the rise in commodity prices lead to difficulties for Chinese factories, a decline in people's consumption level, and an increase in unemployment. Generally speaking, the United States' QE4 brings a negative impact on China. Though it is difficult to get to know the specific impacts from the U.S. 's exiting plan, the Chinese government should combine the experiences and effects related to the past QE policy to predict the possible effects and take actions to meet the unknown challenges. The study combines SWOT analysis with QE policy, enriching the conclusions about the impact of QE policy, and also analysis the possible impact of QE4 and make suggestions to reduce the impact on China based on experience. Therefore, China can get comprehensive preparations for the U.S. 's exiting, which will help save or at least maintain the market within control, remaining a steady financial market. Whether the U.S. 's exiting plan would make impacts and the extent of impact from the exiting are still unknown until the U.S. makes certain steps. The research related to the impact of the U.S. 's exiting of the QE policy is needed to be pushed to get a deeper studying in the future. These results shed light on both positive and negative can be brought from the QE, which suggest countries need to get preparations and specific steps to respond to the QE policy, according to their country's economic and political conditions.

\section{REFERENCES}

[1] Mou, Jinjin. "Research on the Impact of COVID19 on Global Economy. " IOP Conference Series. Earth and Environmental Science, vol. 546, no. 3, 2020, pp. 32043.

[2] Lewitinn, Lawrence. "QE4 Begins: Fed Cuts Rates, to Buy $\$ 700 \mathrm{~B}$ in Bonds. " Coindesk, 2020. https: //www. coindesk. com/qe4-begins-fed-cuts-ratesbuys-700b-in-bonds-bitcoin-rallies-7-7

[3] "How is the US economy doing compared to prepandemic levels?" USAFACTS. https: //usafacts. org/state-of the union/ economy/? gclid=CjwKCAjw9uKIBhA8EiwAYPUS3E8Ib02 BcLco3nSVSOzFsxx65LAfoNBqu7_SS5Agy_kR Bfaqy9arJBoC3i4QAvD_BwE

[4] "Bernanke: Fed QE GDP Benefits Offset Dollar Impact on Emerging Markets. " The Bond Buyer (New York, N. Y. 1982), vol. 121, no. 33797, 2012.

[5] Yao Bin. "The Effect of Quantitative Easing Monetary Policy in U.S. A and the Countermeasure of China. " Shanghai Finance 07(2009): 33-36.

[6] Liu Xi, and Zhang Qian. "The review and impact analysis of the three quantitative easing policies in the United States. " Bonds 05(2012): 17-21.

[7] Ye Yafei, and Shi Jianxun. "Research on the Dual Impact of the US Quantitative Easing Policy on China's Macroeconomic Development — The Policy Options Under the "Deviation" of China and the United States'Monetary Policy. " Exploration of Economic Issues. 07 (2021): 53- 61. doi: CNKI: SUN: JJWS. 0. 2021-07-007.

[8] Koo, R.C. . "The escape from balance sheet recession and the QE trap : a hazardous road for the world economy. " J. Wiley (2014).

[9] Liao Wenqiang, Lu Jichao, and Bai Caiquan. "The Economic Analysis of QE3 and China's Countermeasures. " Modern Business . 12(2013): 88-90. doi: 10. 14097/j. cnki. 5392/2013. 12. 089.

[10] Zhang Xiaofen, Zhang Yu, and $\mathrm{Lu}$ Jiacong. "Comparison of the effects of three quantitative 
easing monetary policies in the United States. " Business Times . 06(2013): 72-73. doi: CNKI: SUN: SYJJ. 0. 2013-06-030.

[11] Ma Li, Liu Yi, and Lou Tiantian. "The Spillover Effect of the Implementation and Exit of the U.S. Quantitative Easing Monetary Policy: A Literature Review. " Financial Supervision Research. 05 (2015): 75-90. doi: 10. 13490/j. cnki. frr. 2015. 05. 006.

[12] Mosser, Patricia C. "Central Bank Responses to COVID-19. " Business Economics (Cleveland, Ohio), vol. 55, no. 4, 2020, pp. 191-191.

[13] Zhang Qian. "The impact of the Fed's monetary policy on emerging markets. " Financial Expo. 06
(2021): 56-57. Doi: CNKI: Sun: xxjr. 0. 2021-06027

[14] Huang Xianfu. (2011). The impact of the US quantitative easing policy on emerging market countries in the Asia-Pacific region. Asia Pacific Economics (02), 32-34. doi: 10. 16407/j. cnki. 1000-6052. 2011. 02. 024.

[15] Yi Xianrong. (2014). The market uncertainty effect of the withdrawal of the US quantitative easing policy. Finance, Trade and Economics (05), 39-50. doi: 10. 19795/j. cnki. cn11-1166/f. 2014. 05. 004 .

[16] Ao Yiman. "The impact of the "unlimited" quantitative easing policy in the United States under the new crown epidemic and its countermeasures. " China Business Review 5: 2. 